\title{
PERLINDUNGAN ANAK DALAM PERSPEKTIF ISLAM
}

\author{
Zulfa Ahmad*
}

\begin{abstract}
This paper deals with the problem of child protection from an Islamic perspective. It starts by discussing the Islamic teaching concerning family values and the function of family in child education as well as the responsibility of the family in protecting the children. By extension the paper is also concerned with the idea of marriage, its meaning and function in social life. We base our analysis on the Qur'anic verses but also on the child protection law number 23 year 2002 . We basically argue that it is up to the family to raise the children in a positive or negative manner. The very structure of family is very much relevant to the upbringing of the children and that their positive or negative attitude is dependent upon the nature of the surrounding in which they live.
\end{abstract}

Keywords: child protection, family, marriage

\section{Pendahuluan}

Perlindungan Anak dalam Perspektif Islam merupakan persoalan yang sangat penting dan mendesak untuk dibicarakan. Penting dan mendesak mengingat beberapa tahun belakangan ini kita seringkali disuguhi berbagai berita dan informasi tentang berbagai tindak kekerasan terhadap anak yang dilakukan oleh orang-orang yang seharusnya bertanggung jawab melindungi anak-anak tersebut. Bahkan juga terjadi eksploitasi seksual terhadap anak. $\mathrm{Hal}$ ini tentu menunjukkan betapa rendahnya perlindungan terhadap anak, meskipun Indonesia telah memiliki Undang-Undang Nomor 23 tahun 2002 tentang Perlindungan Anak. Permasalahan mengenai perlindungan terhadap anak ini bukan saja penting dan mendesak untuk dibicarakan, melainkan juga penting dan mendesak untuk disosialisasikan kepada segala pihak yang bertanggung jawab terhadap perlindungan anak agar mereka memahami hak-hak anak, dan kewajiban mereka untuk memberikan perlindungan, kesejahteraan, dan rasa aman kepada anak.

Dari judul Perlindungan Anak dalam Perspektif Islam, setidaknya ada empat persoalan yang harus dibicarakan, yaitu:

1. Fungsi-fungsi Keluarga

2. Anak dalam pandangan Islam

3. Makna dan bentuk perlindungan anak, dan

4. Pelindung Anak

\section{Fungsi-fungsi Keluarga}

Sebelum membahas lebih jauh tentang perlindungan anak dalam perspektif Islam, ada baiknya terlebih dahulu kita meninjau sekilas tentang fungsi-fungsi keluarga, di mana saya akan mencoba melihat bagaimana keluarga seyogianya menjalankan fungsi-fungsi tersebut sebagai sebuah tanggung jawab dalam kehidupan berkeluarga, sebab tujuan berkeluarga pada dasarnya adalah untuk membangun kehidupan agar berada dalam kondisi yang sakinah dan mawaddah,

*Universitas Islam N egeri (UIN) Syarif Hidayatullah J akarta 
yaitu kondisi yang aman, tenteram, serta penuh dengan rasa cinta dan kasih sayang. Kondisi demikian tentu bisa diciptakan jika berbagai aspek kehidupan mendapat perhatian dan perlindungan.

Untuk mencapai kondisi tersebut, maka Islam mensyariatkan agar pergaulan laki-laki dan perempuan yang bukan muhrim, tanpa melihat apakah sudah menikah atau belum, harus berada dalam batas-batas aturan moral yang ditetapkan Islam, sebagaimana difirman Allah dalam surah al-Nurayat 30-31., yang berbunyi :

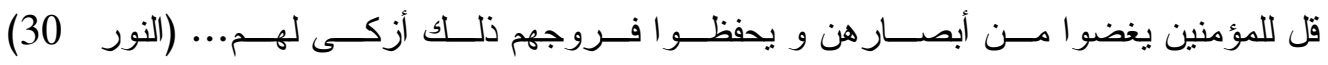

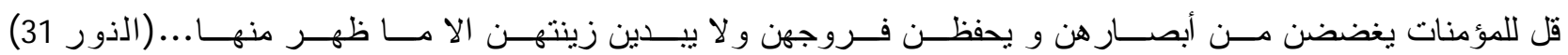

Artinya: Katakanlah kepada orang-orang mukmin (laki-laki) hendaklah mereka menundukkan pandangan mereka dan menjaga faraj mereka, yang demikian lebih baik baik bagi mereka... (ayat 30) Dan katakanlah kepada perempuan-perempuan mukmin, hendaklah mereka menundukkan pandangan mereka dan menjaga faraj mereka, dan janganlah mereka tampakan perhiasan mereka kecuali apa yang biasa tampak..... (ayat 31)

Quraish Shihab dalam Tafsir al-Mishbah berkenaan dengan ayat 30 ini menyatakan bahwa Allah menghendaki agar laki-laki mukmin mengendalikan/menundukkan pandangan mereka dan memelihara furujmereka. Sementara melalui ayat 31 hal yang sama ditujukan pula kepada para perempuan mukminah. Selain itu, kepada perempuan mukminah Allah juga memerintahkan untuk menutup aurat, kecuali apa yang biasa tampak ${ }^{1}$.

Ketika seseorang berkeinginan untuk menikah, maka berdasarkan hadis yang diriwayatkan oleh al-J amaah, Islam memberi petunjuk agar memilih istri karena empat alasan, yaitu : 1) hartanya, 2) keturunannya, 3) kecantikannya, dan 4) agamanya. Pilihan terbaik adalah pilihan yang didasarkan kepada alasan agama. Tentu menjadi tanda tanya, kenapa Islam menganjurkan alasan agama untuk menikah. Secara gamblang hal ini dapat dikatakan bahwa seorang perempuan yang beragama tentu akan mengendalikan rumahtangganya dan menjalankan fungsifungsi keluarganya sesuai ajaran agama. Dan saya kira pria yang beragama pulalah yang ingin menikahi seorang perempuan beragama, dan menjalankan kepemimpinan di dalam rumah tangga sesuai petunjuk agama. Dan seorang perempuan yang beragama tentu hanya akan menerima pinangan dari laki-laki yang beragama pula. Kalau demikian adanya, maka upaya untuk menjalankan fungsi-fungsi keluarga akan berjalan lebih baik, sebab keluarga tersebut dipimpin oleh seorang kepala keluarga yang beragama.

Berbicara tentang fungsi-fungsi keluarga, ada baiknya sejenak kita melihat kembali apa yang dikatakan Imam al-G hazaliłbeberapa abad yang lalu mengenai lima prinsip dasar yang ditetapkan oleh syariat Islam untuk meningkatkan martabat kemanusiaan, yaitu: kematangan beragama, perlindungan pribadi, pengembangan penalaran, pembinaan anak-anak, dan pemeliharaan harta benda. ${ }^{2}$ Dari kelima prinsip dasar ini dapat ditarik benang merah yang menunjukkan bahwa pada dasarnya prinsip-prinsip ini mempunyai hubungan yang erat dengan

${ }^{1}$ M. Quraish Shihab, Tafsir al-M ishbah Vol. 9 (J akarta : Lentera H ati), 2002, 324 - 326

${ }^{2} \mathrm{~N}$ asution, Khadijah, Poligami ditinjau dari Segi Agama, Sosial, dan Perundang-undangan (J akarta: Bulan B intang, 1976), 147. 
masalah perlindungan, yaitu perlindungan beragama, pribadi termasuk anak, intelektual, kualitas anak, dan harta benda. Berkenaan hadis Rasulullah Saw. yang berbunyi :

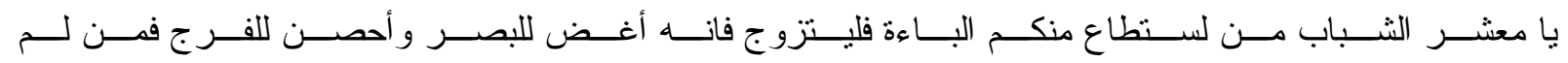

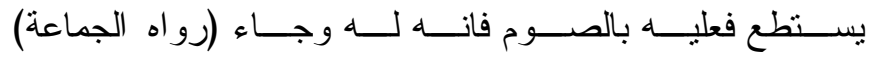

Artinya : Wahai para pemuda, jika kamu telah mempunyai Ba'gh, maka hendaklah engkau menikah, karena sesungguhnya menikah itu dapat menjaga pandangan dan faraj. Barangsiapa yang tidak sanggup hendaklah ia berpuasa.

Nasution ${ }^{3}$ yang mengutip pendapat 'A bdu al-Nashir menyatakan bahwa kesanggupan untuk menikah yang dinyatakan oleh hadis Nabi Saw., dengan istilah al-ba'gh, adalah kesanggupan untuk menjalankan fungsi sebagai kepala keluarga, kemampuan ekonomi, kemampuan biologis, kemampuan sosial, dan kemampuan agama. Kelima kemampuan ini tampaknya juga merupakan fungsi-fungsi perlindungan yang harus dilaksanakan oleh sebuah keluarga.

Secara sosiologis menurut Melly ${ }^{4}$ sebuah keluarga harus menjalankan fungsi-fungsi keluarga sebagai upaya sebuah keluarga sebagai lembaga sosial untuk mewujudkan keluarga yang aman, tenteram, bahagia, dan sejahtera. Dalam rangka itu secara sosiologis ada sembilan fungsi keluarga, yaitu : 1) Fungsi Biologis, 2) Fungsi Ekonomi, 3) Fungsi Kasih Sayang, 4) Fungsi Pendidikan, 5) Fungsi Perlindungan, 6) Fungsi Memasyarakatkan (Sosialisasi) Anak, 7) Fungsi Rekreasi, 8) Fungsi Status Keluarga, dan 9) Fungsi Beragama. Kesembilan fungsi ini menurutnya dalam praktek kehidupan sehari-hari saling bertautan dan saling melengkapi.

Jika dihubungkan dengan masalah perlindungan anak, maka kesembilan fungsi ini sebenarnya mempunyai fungsi perlindungan terhadap anak yang harus dilaksanakan oleh kedua orang tuanya. Meskipun demikian, adakalanya orang tua tidak dapat melaksanakan fungsi perlindungan ini, sehingga diperlukan kepedulian orang lain atau lembaga lain untuk menjalankan fungsi ini.

Di dalam Islam ditemukan prinsip-prinsip perlindungan terhadap anak sebagaimana perintah Allah terhadap penanggung jawab keluarga agar memelihara keluarganya dari api neraka, sebagaimana difirmankan dalam surah al-Tahrijim ayat 6 yang berbunyi :

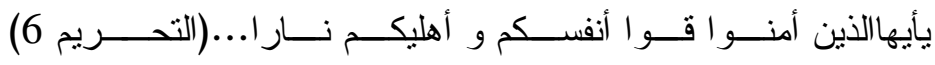

Artinya : "... peliharalah diri dan keluargamu dari api neraka..."

Quraish Shihab mengatakan ayat 6 al-Tahrijin ini menggambarkan bahwa dakwah dan pendidikan harus bermula dari rumah ... Ayat ini secara redaksional tertuju kepada laki-laki tetapi itu bukanlah berarti hanya kepada lelaki semata melainkan kepada laki-laki dan perempuan (ayah dan ibu). Ini berarti bahwa kedua orang tua bertanggung jawab terhadap anak-anak dan juga pasangan masing-masing, sebagaimana masing-masing bertanggung jawab atas kelakuannya. Ayah atau ibu sendiri tidak cukup untuk menciptakan satu rumah tangga yang diliputi oleh nilai-nilai agama serta dinaungi oleh hubungan yang harmonis 5 .

Ayat Allah ini setidaknya memperlihatkan perhatian Islam akan betapa pentingnya

3Melly Sri Sulastri Rifai, Suatu Tinjauan Historis Prospektif tentang Perkembangan Kehidupan dan Pendidikan Keluarga, dalam Keluarga Muslim dalam M asyarakat Modern (Bandung: Remaja Rosda Karya, 1993), 7-13.

${ }^{4}$ M. Q uraish Shihab, Tafsir al-M ishbah, Vol. 14 (J akarta: Lentera Hati, 2002), 327.

5 Undang-Undang N omor 23 Tahun 2002 tentang Perlindungan Anak dalam Penghapusan Eksploitasi Seksual Komersial 
perlindungan terhadap anak-anak agar mereka tidak mengalami kesengsaraan di dunia dan akhirat. $\mathrm{H}$ al ini sekaligus memperlihatkan bahwa fungsi utama dari sebuah keluarga dalam Islam adalah sebagai sarana pembinaan generasi berkualitas, yang hidup sejahtera di dunia dan di akhirat.

\section{Anak dalam Pandangan Islam}

Anak dalam pandangan Islam dapat berada pada posisi negatif dan dapat pula pada posisi positif. Penempatan anak pada dua posisi ini pada dasarnya merupakan peringatan kepada kedua orang tua agar melindungi anak-anaknya supaya jangan menjadi anak dalam makna negatif. Kedua hal ini dapat kita telusuri dari beberapa ayat al-Quran dan hadis Rasulullah sebagai berikut.

1. Anak-anak pada sisi negatif dapat dilihat sebagai berikut:

- Anak sebagai makhluk yang tidak tau apa-apa, sebagaimana difirmankan Allah dalam alNahljayat 78 yang bunyinya:

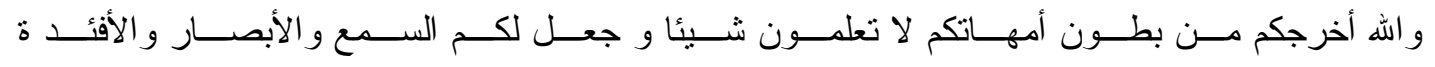

(7\%rtinyid'): “dan Allah mengeluarkan kamu dari perut ibumu dalam keadaan tidak mengetahui sesuatupun dan Dia memberi kamu pendengaran, penglihatan, dan hati, agar kamu bersyukur".

Makna ayat ini tampaknya sejalan dengan hadis Rasulullah yang diriwayatkan oleh Bukhari dan Muslim yang berbunyi :

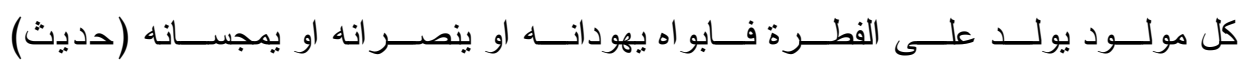

Artinya : "Setiap anak dilahirkan dalam keadaan fitrah, maka kedua orang tuanyalah yang menjadikannya Yahudi, Nashrani, atau Majusi"

- Anak sebagai musuh, sebagaimana digambarkan Allah dalam surah al-Taghabun ayat 14 yang berbunyi :

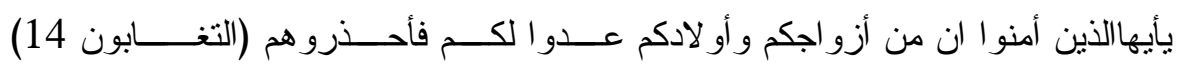

Artinya “... sesungguhnya di antara pasanganmu dan anak-anakmu itu adalah musuhmu, maka berhati-hatilah terhadap mereka"

- Anak sebagai cobaan sebagaimana terungkap dari firman Allah dalam surah al-Anfabayat 28 yang bunyinya :

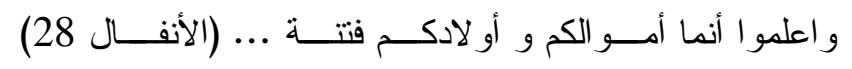

Artinya "... dan ketahuilah bahwa hartamu dan anak-anakmu itu hanyalah sebagai cobaan..."

Dan juga dalam al-Taghabun ayat 15 :

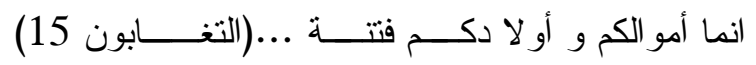
Artinya "... sesungguhnya hartamu dan anak-anakmu adalah cobaan..."

- Anak tidak bermanfaat untuk menolak siksaan Allah, sebagaimana dalam firman Allah dalam surah al'Imran ayat 116 :

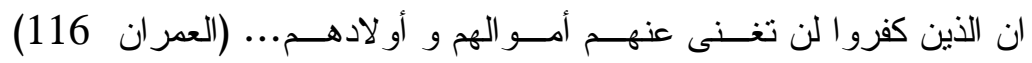
Artinya : Sesungguhnya orang-orang yang kafir tidak bermanfaat bagi mereka harta 
mereka dan anak-anak mereka .....

Dan dalam surah al-Syuarałayat 88 yang berbunyi :

Artinya : "pada hari harta dan anak-anak tidak berguna"

يوم لا ينفــع مــال و لا بنــــن (الثــعر اء 88)

- Anak sebagai sesuatu yang dapat memalingkan seseorang dari jalan Allah, sebagaimana firman Allah dalam surah al-Taubah ayat 24 yang berbunyi :

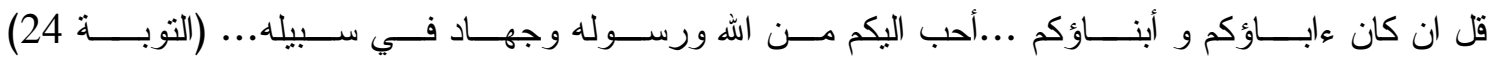
Artinya : "Katakanlah jika bapak-bapakmu, anak-anak kamu... lebih kamu cintai dari pada Allah dan RasulNya dan berjihad di jalanNya, maka tunggulah sampai Allah mendatangkan keputusannya..."

- Anak sebagai pribadi durhaka dan kafir sebagaimana difirmankan Allah dalam surah alKahfi ayat 80 :

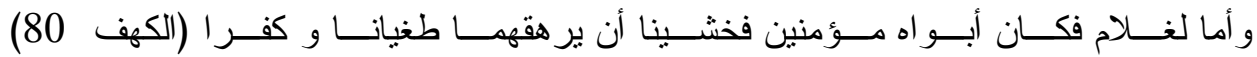
Artinya : "dan adapun anak remaja, maka kedua orang tuanya adalah dua orang mukmin, dan kami khawatir dia akan membebani kedua orang tuanya kedurhakaan dan kekufuran"

- Anak sebagai pribadi yang tidak dapat mendekatkan seseorang dengan Allah, sebagimana firmanNya dalam surah Saba' ayat 37 :

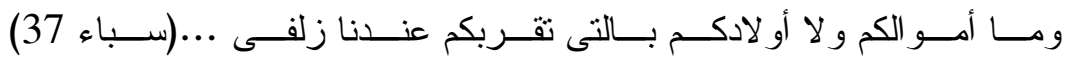

Artinya : "dan sekali-kali bukanlah harta dan bukan pula anak-anak kamu yang akan mendekatkan kamu ke sisi Kami sedikitpun..."

- Dan sebagainya.

2. Anak-anak pada sisi positif.

Al-Q uran juga menggambarkan anak-anak dari sudut positifnya, yang antara lain dapat ditelusuri dari berbagai ayat dan hadis Rasulullah sebagai berikut:

- Anak sebagai qurratu 'ain atau penyejuk mata sebagaimana terungkap dari firman Allah dalam surah al-Furqan ayat 74 yang berbunyi :

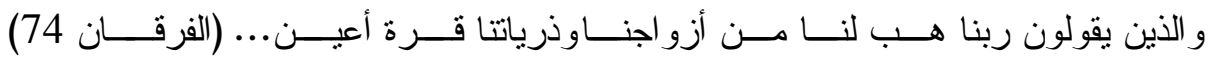
Artinya "... dan mereka senantiasa berkata: Tuhan kami, anugerahkanlah buat kami dari pasangan-pasangan kami, penyejuk mata..."

- Anak sebagai hamba yang tidak musyrik sebagaimana difirmankan Allah dalam surah Luqman ayat 13 :

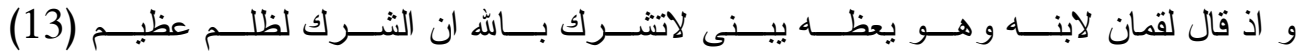
Artinya "Ingatlah ketika Lukman berkata kepada anaknya memberi nasihat, wahai anakku, janganlah engkau memperserikatkan Allah..."

- Anak sebagai pribadi yang santun sebagaimana digambarkan dalam surah al-Shaffatayat 101 :

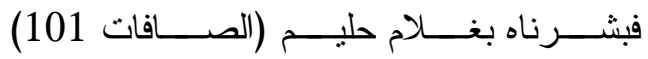

Artinya "Maka Kami memberinya kabar gembira dengan seorang anak yang santun" 
- Anak sebagai pribadi yang suka berbuat baik sebagaimana difirmankan Allah dalam surah al-Shaffatayat 113 :

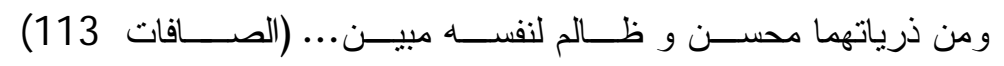

Artinya "... dan di antara anak cucu keduanya ada yang muhsin dan ada pula yang zalim terhadap dirinya sendiri..."

- Anak sebagai pribadi yang berbakti kepada kedua orang tuanya, sebagaimana difirmankan Allah dalam surah al-Ahgasayat 15

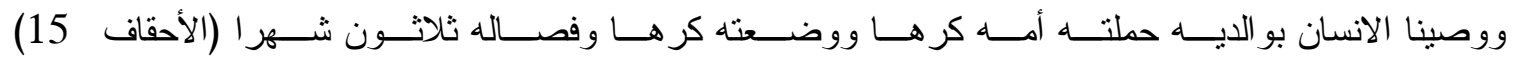
Artinya "Dan Kami telah mewasiatkan kepada manusia agar berbuat baik kepada kedua orang tuanya..."

- Anak sebagai pribadi yang alim yang tergambar dalam firman Allah surah al-Dzakiyatayat 28 :

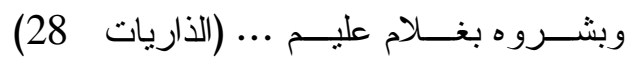

Artinya “... mereka menyampaikan kabar gembira kepadanya tentang seorang anak yang alim."

- Anak sebagai pribadi yang beriman sebagaimana firman Allah dalam surah al-Thurayat 21:

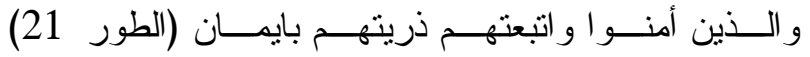
Artinya “... dan orang-orang yang beriman, dan yang anak cucu mereka mengikuti mereka dalam keimanan..."

Kedua orang tua punya peran penting untuk memfungsikan pendidikan keluarga dan memberikan perlindungan pada anak agar anak menjadi pribadi yang bernilai positif, dan terjauh dari berbagai sikap negatif yang dapat merugikan dirinya dan diri orang lain di sekitarnya, maupun lingkungan.

\section{Makna dan Bentuk Perlindungan Anak}

Sebelum mendiskusikan mengenai makna dan perlindungan anak dalam perspektif Islam, saya akan menyinggung sekilas tentang makna dan bentuk perlindungan sebagaimana diatur oleh Undang-Undang Nomor 23 Tahun 2002 tentang Perlindungan Anak. Menurut Undangundang ini "anak adalah seseorang yang belum berusia 18 tahun, termasuk anak yang masih dalam kandungan" (Pasal 1 ayat (1)) dan "perlindungan anak adalah segala kegitan untuk menjamin dan melindungi anak dan hak-haknya agar dapat hidup, tumbuh, berkembang, dan berpartisipasi secara optimal sesuai dengan harkat dan martabat kemanusiaan, serta mendapat perlindungan dari kekerasan dan diskriminasi" (Pasal 1 ayat (2)). ${ }^{6}$ Dari ketentuan UndangUndang Nomor 23 Tahun 2002 dapat diketahui bahwa anak yang ada dalam kandungan hingga berusia 18 tahun mendapat perlindungan akan hak-hak hidup, tumbuh, dan berkembang, serta dari berbagai kekerasan dan diskriminasi. Batasan ini menunjukkan bahwa upaya perlindungan

Anak (J akarta: Departeman Kominfo RI dan Badan Informasi Publik Pusat Informasi Kesejahteraan Rakyat, 2005), 75.

${ }^{6}$ M. Q uraish Shihab, Tafsir al-M ishbah, Vol. 10 (J akarta: Lentera H ati, 2002), 407 - 408. 
yang dilakukan hanyalah sebatas perlindungan duniawi dan material saja. Pertanyaannya adalah bagaimana dengan perlindungan terhadap kehidupan akhirat dan moral anak. Di sinilah agaknya letak keunggulan Islam yang mempunyai aturan yang ditujukan untuk memberikan perlindungan bagi manusia, termasuk anak, bagi kesejahteraan hidup dunia maupun akhirat. Allah menggambarkan hal tersebut dalam surah al-Q ashash ayat 77 yang berbunyi :

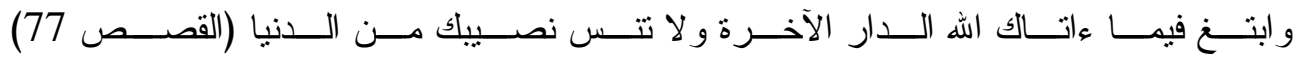

Artinya : "dan carilah apa yang telah dianugerahkan Allah untuk kepadamu (kebahagiaan) negeri akhirat, dan janganlah kamu melupakan bahagianmu dari (keni'matan) duniawi"

Mengomentari ayat ini Quraish Shihab menggarisbawahi tiga hal. "Pertama, dalam pandangan Islam hidup duniawi dan ukhrawi merupakan satu kesatuan. Dunia tempat menanam dan akhirat tempat menuai. A pa yang anda tanam di sini, akan memperoleh buahnya di sana. Islam tidak mengenal istilah amal dunia dan amal akhirat.... Kedua, adalah suatu hal yang penting untuk mengarahkan pandangan kepada akhirat sebagai tujuan dan kepada dunia sebagai sarana untuk mencapai tujuan... Ketiga, ayat di atas menggunakan redaksi yang bersifat aktif ketika berbicara tentang kebahagiaan akhirat bahkan menekankannya dengan perintah untuk bersungguh-sungguh dan dengan sekuat tenaga berupaya meraihnya. Sedangkan perintah menyangkut kebahagiaan duniawi berbentuk pasif. $\mathrm{H}$ al ini mengesankan perbedaan antara keduanya"7.

Berbicara tentang anak, Islam juga memperhatikan kebutuhan anak sejak janin berada dalam kandungan, bahkan proses perlindungan itu sudah harus diberikan sejak :

1. Memilih jodoh, di mana Rasulullah memberi petunjuk agar seorang laki-laki memilih seorang perempuan, di mana ia akan menumpahkan nuthfahnya, - yang oleh al-Quran diibaratkan sebagai “ladang/hærrtsun” - karena hartanya, keturunannya, kecantikannya atau agamanya. Rasulullah merekomendasikan agar memilih pasangan lantaran agamanya. ${ }^{8}$ Meskipun sabda Rasulullah terkait dengan rekomendasi terhadap laki-laki yang akan memilih pasangan hidup, perempuan pun dalam menjatuhkan pilihan tentu juga harus memperhatikan rekomendasi ini.

2. Memasuki kehidupan rumah tangga dimulai dengan aqad, yang merupakan perjanjian suci seorang laki-laki dan perempuan di depan Allah Swt., yang di dalam surah al-Nisa' ayat 21 disebut sebagai mitsaqan ghalizha.

3. Rasulullah menyuruh pasangan suami istri yang akan melakukan hubungan khusus, memulainya dengan doa.

4. Ketika seorang perempuan berada dalam masa kehamilan, dianjurkan banyak membaca alQuran.

5. Ketika seorang bayi lahir, Islam juga mensyariatkan agar dibacakan adzan di telinganya.

6. Ketika ia akan disusukan ibunya, ibu hendaknya membiasakan diri memulai dengan bacaan basmalah dan mengakhiri dengan bacaan hamdalah.

Beberapa langkah yang dirinci ini setidaknya dapat menggambarkan betapa besar perhatian Islam terhadap perlindungan beragama seorang anak agar ia memiliki fondasi pembangunan

${ }^{7}$ Ny. Hadiyah Salim, Mukhtar al-A hadits. (Bandung: al-Maarif, 1983), 286.

${ }^{8}$ Terjemahan ayat dikutip dari Q uraish Shihab, Tafsir al-M ishbah/ volume I (J akarta: Lentera Hati, 2006), 503. 
nilai positif yang kelak dapat dikembangkan. Hal ini tergambar dalam firman Allah dalam surah al-Baqarah ayat 132 yang berbunyi :

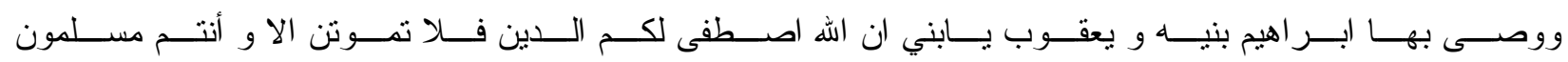

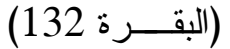

Artinya : "Dan Ibrahim telah berwasiat kepada anak-anaknya, demikian juga Ya'qub. (Ibrahim berkata) : Hai anak-anakku, sesungguhnya Allah telah memilih agama ini bagimu, maka janganlah lamu mati kecuali dalam memeluk agama Islam"

Selanjutnya berkenaan dengan perlindungan yang bersifat duniawi, al-Q uran antara lain menyatakan bahwa :

1. Bayi harus mendapatkan gizi yang baik dan sempurna, sebagaimana firman Allah dalam surah al-Baqarah ayat 233 yang berbunyi :

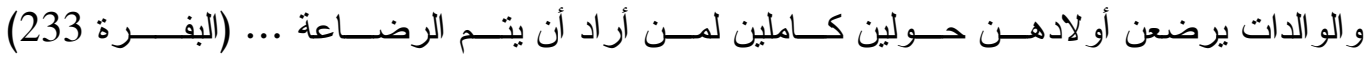
Artinya "para ibu menyusukan anaknya selama dua tahun penuh bagi yang ingin menyempurnakan penyusuan. Dan menjadi kewajiban bagi bayi itu yang dilahirkan untuknya (ayahnya sang bayi) memberi rezeki (makanan) dan pakaian kepada para ibu dengan cara yang makruf... dst" 9

Berdasarkan ayat 233 ini, menurut Quraisy Shihab Allah menganjurkan dengan sangat, atau bahkan seakan-akan mewajibkan agar al-walidatmemberikan Air Susu Ibu (ASI) selama dua tahun kepada bayinya. Menurutnya ayat 233 surah al-Baqarah sengaja menggunakan istilah al-walidatbukan al-ummahat, sebab kata al-walidatberarti para ibu, baik kandung maupun bukan, sedangkan al-ummahatberarti ibu kandung. Dengan ini, maka al-Quran menggariskan bahwa pemberian ASI adalah terbaik untuk bayi yang harus diberikan maksimal selama 2 tahun, baik oleh ibu kandung atau bukan. Sementara itu, ayah dari bayi tersebut berkewajiban:

- Membiayai penyusuan agar kesehatan ibu terjamin, dan ASI selalu tersedia. Kelanjutan ayatjuga membebani ayah dengan kewajiban memberi makan dan pakaian ibu bayi (istri ayah) jika ibu tersebut dalam kondisi ditalak ba'in.

- Jika dalam kondisi talak raj'i, maka kewajiban makan dan pakaian ibu bayi (istri ayah) adalah atas dasar kewajiban ayah dalam hubungan suami istri. Kewajiban ayah tersebut menurut Q uraisy Shihab adalah lantaran anak tersebut membawa nama ayah. ${ }^{10}$

2. Perlindungan gizi sebagaimana digambarkan pada angka 1 dimaksudkan agar anak yang dilahirkan mendapat jaminan pertumbuhan fisik dan perkembangan jiwa dengan baik.

3. Masa menyusukan bayi menurut Quraish Shihab tidak harus selalu 2 tahun ( 24 bulan) sebab surah al-Ahфjafayat 15 menyatakan bahwa masa hamil dan masa menyusui adalah 30 bulan. J ika merujuk ke surah Al-Baqarah ayat 233 maka masa menyusui yang sempurna adalah 24 bulan. Betapapun ayat di atas menunjukkan betapa pentingnya ibu menyusukan anak dengan ASI ${ }^{11}$.

4. Islam juga menggariskan perlindungan fisik bagi anak, sehingga mereka mendapathak hidup yang layak. Gambaran ini diperoleh dari cercaan al-Q uraß teradap orang yang membunuh

${ }^{9}$ Baca ibid., h. 504.

${ }^{10}$ M. Q uraish Shihab, Tafsir al-M ishbah, Vol. 13, (J akarta: Lentera H ati, 2002), 89.

${ }^{11}$ M. Q uraish Shihab, Tafsir al-M ishbah, Vol. 11, (J akarta: Lentera Hati, 2002), 127. 
anaknya, sebagaimana firman Allah dalam ayat 140 surah al-An'am yang berbunyi :

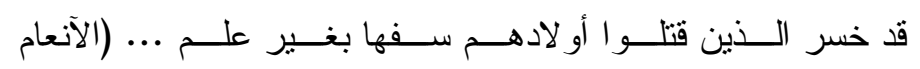

Artinya: "Sesungguhnya telah merugi orang-orang yang yang telah membunuh anakanak mereka karena kebodohan lagi tanpa pegetahuan...",

J uga firman Allah dalam surah yang sama ayat 151 yang melarang tegas membunuh anak-anak, yang berbunyi:

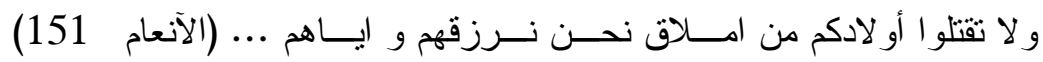
Artinya : “... janganlah kamu membunuh anak-anak kamu karena kemiskinan, kami akan memberi rezki kepadamu dan kepada mereka..."

5. Melalui surah Luqman ayat 13 sampai dengan ayat 19 dapat pula dirinci perlindungan pendidikan yang harus diberikan pada anak, yaitu:

- Nasihat Luqman pada anaknya agar tidak memperserikatkan Allah (ayat 13). Menurut Quraisy Shihab larangan ini sekaligus mengandung pengajaran tentang wujud dan keesaan Allah. ${ }^{12}$ Ini merupakan upaya perlindungan mental yang sangat kuat.

- Bersyukur pada Allah karena Dia yang menciptakan, dan pada kedua orang tua, lantaran keduanya menjadi perantara kelahiran dan ibunya telah mengandungnya dalam keadaan lemah dan semakin lemah. Ini merupakan perlindungan dari sikap sombong dan tidak tahu diri (ayat 14).

- J ika kedua orang tua memaksa untuk mempersyerikatkan Tuhan, maka tidak perlu ditaati, namun tetap memperlakukan keduanya dengan baik (ayat 15) Hal ini menunjukkan perlindungan iman yang berjalan bersama dengan perlindungan sikap sopan.

- Jika ada seberat sawi sekalipun yang berada dalam batu karang, atau langit atau bumi, Allah sangat mengetahuinya (ayat 16). Hal ini menggambarkan kemahakuasaan Allah, dan sekali perlindungan pada anak untuk selalu mengerjakan segala kebaikan, betapapun kecilnya.

- Mendirikan Shalat, menyuruh yang makruf, melarang yang mungkar, bersabar atas mushibah yang menimpa (ayat 17). Menurut Quraisy Shihab ayat ini merupakan kesinambungan tauhid serta kehadiran Tuhan dalam kalbu anak. Dari ayat ini tampak perlindungan terhadap aktivitas anak, baik dalam masalah ibadah, menyeru kebaikan dan melarang kemungkaran, serta sikap sabar.

- J angan memalingkan muka dari manusia, jangan berjalan di muka bumi dengan angkuh, sederhana dalam berjalan, dan lunakkan suara (ayat 18 dan 19). Ayat ini menggambarkan hal-hal yang terkait sopan santun anak, yang pada akhirnya merupakan perlindungan terhadap perilaku anak.

Dari uraian ini dapat kita mengambil gambaran bahwa anak dalam pandangan Islam mempunyai makna sebagai penerus garis keturunan yang tetap dalam kondisi iman kepada Allah, dan karena itu anak harus dilindungi baik secara fisik dengan memberikan makanan yang bergizi, maupun secara psikis anak menanamkan keyakinan beragama sejak anak berada dalam kandungan dan bahkan ketika sepasang anak manusia akan mencari jodoh.

12 Ibid., 136. 


\section{Pelindung Anak}

J ika demikian banyak perlindungan yang harus diberikan pada anak dalam rangka mempersiapkan mereka agar dapat melindungi diri sendiri, permasalahannya adalah siapa sebenarnya yang menjadi penanggung jawab terhadap perlindungan anak. Merujuk kepada alQuran surah al-Tahrim ayat 6 yang berbunyi :

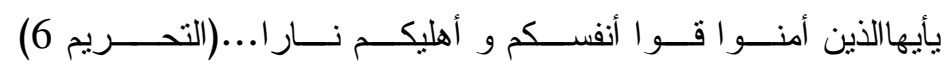

Artinya: "Wahai orang-orang yang beriman, pelaharalah dirmu dan keluargamu dari api neraka...",

Dan hadis Rasulullah saw., yang diriwayatkan oleh Abu Hurairah r.a, yang berbunyi :

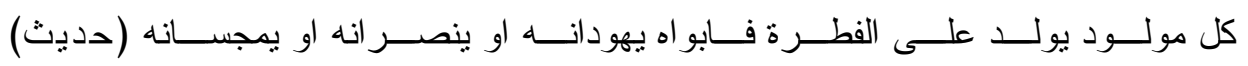

Artinya: "Setiap anak dilahirkan dalam keadaan fitrah, maka kedua orang tuanya lah yang menyebabkan anaknya menjadi Yahudi, Nashrani, atau Majusi",

Dari ayat dan hadis Rasulullah saw ini, terlihat jelas bahwa penanggung jawab utama atas perlindungan anak adalah kedua orang tua anak tersebut. Adakalanya kedua orang tua tidak dapat melaksanakan fungsi perlindungan ini, maka al-Q uran melalui ayat 215 surah al-Baqarah menyatakan :

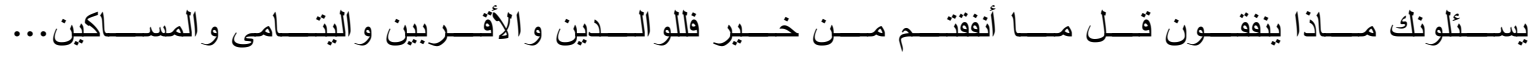

Artinya "Mereka bertanya kepadamu tentang apa yang mereka nafkahkan. J awablah,

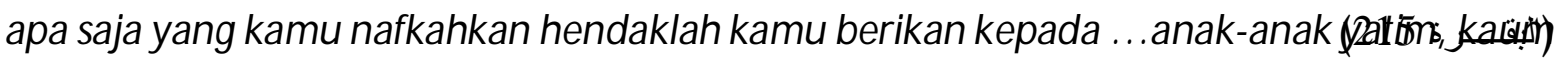
miskin,....".

Selain itu dalam Islam ada kewajiban mengeluarkan zakat bagi yang mampu, di mana zakat ini dapat pula dikelola oleh negara. Dengan ketentuan ini tampaklah bahwa ketika kedua orang tua seorang anak tidak mampu melakukan fungsi perlindungan yang menjadi tanggung jawab mereka, maka fungsi tersebut, dapat diambil alih oleh orang lain, organisasi, maupun negara.

Demikianlah persepsi Islam tentang perlindungan anak yang pada dasarnya masih bersifat umum, dan perlu dibuat rincian yang mudah untuk dioperasionalkan.

Demikian pula sepintas pandangan saya mengenai Perlindungan Anak dalam Perspektif Islam dalam tulisan ini, semoga ada manfaatnya.

\section{Daftar Rujukan}

Departemen Agama RI, Al-Qur'an dan Terjemahnya. J akarta: tt.

Departemen Kominfo RI dan Badan Informasi Publik Pusat Informasi Kesejahteraan Rakyat. "Undang-Undang N omor 23 Tahun 2002 tentang Perlindungan Anak" dalam Penghapusan

Eksploitasi Seksual Komersial Anak. J akarta: Departeman Kominfo RI dan Badan Informasi Publik Pusat Informasi Kesejahteraan Rakyat, 2005.

al-G hazaki>Abu※ did Muhammad. Ihya'>'Ulum al-Din, J uzI (Kairo: Matha'ah al-Azhariyah alMisiliyah, $1302 \mathrm{H}$.

Hadijah Salim. Tarjamah Mukhtarul Ahadis. Bandung: PT. Al-Ma'arif, 1983. 
Melly Sri Sulastri Rifai. "Suatu Tinjauan Historis Prospektif tentang Perkembangan Kehidupan dan Pendidikan Keluarga", dalam Keluarga M uslim dalam M asyarakat Modern. Bandung: Remaja Rosdakarya, 1993.

Nasution, Khadijah. Poligami Ditinjau dari Segi Agama, Sosial, dan Perundang-undangan. J akarta: Bulan Bintang, 1976.

Shihab, Quraish. Tafsir al-M ishbah, volume 1. J akarta: Lentera H ati, 2002. . Tafsir al-M ishbah, volume 7. J akarta: Lentera H ati, J akarta, 2002. . Tafsir al-M ishbah, volume 9. J akarta: Lentera H ati, 2002. . Tafsir al-M ishbah, volume 10. J akarta: Lentera Hati, 2002. - Tafsir al-M ishbah, volume 11. J akarta: Lentera Hati, 2002. - Tafsir al-M ishbah, volume I3. J akarta: Lentera H ati, 2002. . Tafsir al-M ishbah, volume I4. J akarta: Lentera H ati, 2002. 